\title{
Pengaruh Waktu Tahan ketika Proses Thermo Mechanical Controlled Process (TMCP) terhadap Sifat Mekanik dan Fenomena Anneal Hardening Paduan Cu-Zn 70/30
}

\author{
Eka Febriyanti $^{1, \mathrm{a}}$, Amin Suhadi ${ }^{1, \mathrm{~b}}$, Ahmad Fadli $^{2}$, dan Rini Riastuti ${ }^{2}$ \\ ${ }^{1}$ Balai Besar Teknologi Kekuatan Struktur (B2TKS), Badan Pengkajian dan Penerapan Teknologi (BPPT), \\ PUSPIPTEK, Serpong, 16314, Indonesia \\ ${ }^{2}$ Departemen Teknik Metalurgi dan Material, Fakultas Teknik, Universitas Indonesia, Depok, Indonesia

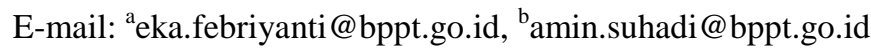

Masuk : 15 Januari 2020

Direvisi :14 Februari 2020

Disetujui : 25 Februari 2020

\begin{abstract}
Abstrak: Paduan $\mathrm{Cu}-\mathrm{Zn}$ 70/30 memiliki sifat konduktivitas panas dan listrik yang sangat baik serta mampu bentuk yang baik. Cu-Zn 70/30 sangat luas digunakan sebagai core dan tank radiator otomotif, komponen amunisi, maupun perangkat bangunan dan arsitektur. Thermo-Mechanical Controlled Processing (TMCP) adalah salah satu metode rangkaian pengontrolan pemanasan dan pembentukan dengan tujuan meningkatkan kualitas sifat material. Oleh karena itu, pada penelitian ini digunakan metode TMCP dengan canai hangat untuk meningkatkan sifat mekanik paduan $\mathrm{Cu}-\mathrm{Zn}$ 70/30. Proses canai dilakukan dengan metode bolak-balik dengan deformasi sebesar 60\% (30\%-30\%) dimana pada setiap pass-nya paduan $\mathrm{Cu}-\mathrm{Zn}$ dipanaskan terlebih dahulu pada temperatur $300^{\circ} \mathrm{C}$ dengan waktu tahan berbeda mulai dari 30, 60, dan 120 menit. Berdasarkan hasil penelitian didapatkan kesimpulan bahwa dengan semakin lamanya waktu pemanasan dan kemudian dideformasi lebih lanjut maka terjadi penurunan mencapai $36,5 \mu \mathrm{m}$ yang berpengaruh pada peningkatan kekerasan sebesar 174,12 HV dan kekuatan tarik mencapai 525,4 MPa pada waktu tahan 120 menit. Ditambah lagi, terdapat indikasi adanya fenomena Anneal Hardening karena tersegregasinya atom terlarut pada dislokasi atau batas butir sehingga memberikan pengaruh yang cukup signifikan terhadap nilai kekerasan dan kekuatan tarik paduan $\mathrm{Cu}-\mathrm{Zn}$ 70/30.
\end{abstract}

Kata kunci: paduan $\mathrm{Cu}-\mathrm{Zn}$ 70/30, TMCP, waktu tahan, sifat mekanis, anneal hardening

Abstract: $\mathrm{Cu}$-Zn alloy (70/30) possesses high thermal, electrical conductivity, and good formability. Thus, used extensively for core and tank automotive radiator, ammunition component, and architectural hardware. Thermo-Mechanical Controlled Processing (TMCP) is one method consists of controlled heating and controlled forming to produce high quality materials. Therefore, this research focuses on the study of mechanical properties and corrosion resistance $\mathrm{Cu}-\mathrm{Zn}$ 70/30 by implementing warm rolling TMCP method. Rolling process was conducted in reversible way with deformation degree of $60 \%(30 \%-30 \%)$ and before each pass of the rolling the material is heated up to temperature $300^{\circ} \mathrm{C}$ with different holding time from 30, 60, and 120 minutes. The results showed that as the longer holding time of the heating and was continued by further deformation, it affects the grain size to be much smaller to 36,5 $\mu \mathrm{m}$ and thus corresponds to the increasing of hardness value up to 174,12 HV dan Ultimate Tensile Strength (UTS) up to 525,4 MPa for 120 minutes of holding time. In addition, it indicates that Anneal Hardening caused by segregation of solute atoms into dislocations or grain boundary has taken place that affect a significant change in hardness and tensile strength of $\mathrm{Cu}-\mathrm{Zn} 70 / 30$.

Keywords: $C u-Z n$ 70/30 alloy, TMCP, holding time, mechanical properties, anneal hardening

\section{PENDAHULUAN}

Tembaga merupakan logam yang memiliki aplikasi yang luas dan bervariasi dalam kehidupan sehari-hari. Tembaga memiliki sifat konduktivitas listrik, konduktivitas panas, serta ketahanan korosi dan pengubahan bentuk yang baik. Tembaga memiliki keuletan dan kelunakan yang tinggi sehingga umumnya tembaga dipadukan dengan elemen lain. Paduan tembaga yang paling umum adalah paduan kuningan dimana seng $(\mathrm{Zn})$ merupakan elemen paduan utama dan dominan dalam kuningan. Paduan Kuningan $(\mathrm{Cu}-\mathrm{Zn})$ yang umum 
diantaranya adalah yellow brass, naval brass, muntz metal (60-40) dan cartridge brass (70-30). Cartridge Brass memiliki sifat kemampuan hantar panas dan listrik serta ketahanan korosi yang baik sehingga umumnya digunakan untuk aplikasi core dan tank radiator otomotif, architectural hardware seperti fasteners, locks, hinges, pins dan rivets, serta komponen amunisi [1].

Selain dengan paduan (alloying), sifat mekanik tembaga juga dapat ditingkatkan dengan perlakuan lain diantaranya adalah dengan metode Thermo-Mechanical Controlled Processing (TMCP). TMCP merupakan rangkaian proses pembentukan (deformasi) dan pemanasan secara simultan untuk mendapatkan kualitas sifat material yang meningkat, umumnya sifat mekanik seperti kekuatan [2]. Metode TMCP yang dilakukan berupa canai (rolling) pada sekitar suhu rekristalisasi $\left(300-350^{\circ} \mathrm{C}\right)$ serta deformasi yang diaplikasikan pada suhu ini tidak terlalu besar layaknya pada hot rolling. Pemilihan metode rolling di sekitar suhu rekristalisasi ini dipertimbangkan karena dapat menurunkan biaya produksi serta kualitas permukaan dan pengontrolan dimensi lebih baik [3].

Penelitian ini merupakan penelitian lanjutan dari penelitian sebelumnya yang dilakukan oleh Eka Febriyanti [4], dimana pada penelitian tersebut dilakukan metode TMCP warm rolling double-pass reversible pada suhu hangat $300^{\circ} \mathrm{C}, 400^{\circ} \mathrm{C}$, dan $500^{\circ} \mathrm{C}$ dengan masing-masing deformasi $50 \%$, $60 \%$, dan $70 \%$ dengan media pendingin berupa udara. Berdasarkan penelitian tersebut dapat disimpulkan bahwa adanya fenomena Anneal Hardening pada suhu $300^{\circ} \mathrm{C}$. Berdasarkan penelitian S. Nestorovic et al [5], Anneal Hardening dipengaruhi oleh unsur paduan, persentase deformasi, dan juga waktu annealing atau waktu tahan.

Oleh karena itu, penelitian ini dilakukan untuk mempelajari pengaruh waktu tahan ketika proses TMCP terhadap perubahan sifat mekanik dan fenomena Anneal Hardening pada paduan $\mathrm{Cu}-\mathrm{Zn}$, dengan harapan dapat meningkatkan kualitas paduan $\mathrm{Cu}-\mathrm{Zn}$ dari sifat mekaniknya.

\section{METODOLOGI}

\section{Persiapan Sampel Uji}

Paduan $\mathrm{Cu}-\mathrm{Zn}$ yang digunakan merupakan klasifikasi paduan $\mathrm{Cu}-\mathrm{Zn}$ 70/30 dengan komposisi paduan hasil optical emission spectroscopy (OES) seperti yang terlihat pada Tabel 1.

Tabel 1. Komposisi sampel paduan $\mathrm{Cu}-\mathrm{Zn} 70 / 30$

\begin{tabular}{ccc}
\hline Unsur & $\begin{array}{c}\text { Penelitian } \\
(\mathrm{wt} \%)\end{array}$ & $\begin{array}{c}\text { Spesifikasi } \\
\text { ASTM } \\
\text { B36M-13[6] } \\
(\% \text { berat })\end{array}$ \\
\hline $\mathrm{Cu}$ & 69,5 & $69,5-72$ \\
$\mathrm{Zn}$ & 30,7 & sisa \\
$\mathrm{Fe}$ & 0,026 & $\sim \max .0,05$ \\
$\mathrm{Sn}$ & 0,0062 & $\sim \max .0,03$ \\
$\mathrm{Al}$ & $<0,002$ & $\sim \max .0,03$ \\
$\mathrm{Ni}$ & - & $\sim \max .0,2$ \\
$\mathrm{As}$ & $<0,001$ & $\sim \max .0,02$ \\
$\mathrm{~Pb}$ & $<0,005$ & $\sim \max .0,05$ \\
$\mathrm{Si}$ & $<0,005$ & $\sim \max .0,01$ \\
$\mathrm{Mn}$ & 0,0052 & $\sim \max .0,04$ \\
$\mathrm{P}$ & $<0,003$ & $\sim \max .0,05$ \\
$\mathrm{Sb}$ & - & $\sim \max .0,01$ \\
$\mathrm{Bi}$ & - & $\sim \max .0,04$ \\
\hline
\end{tabular}

Sampel yang digunakan pada penelitian merupakan lembaran pelat dengan dimensi ukuran panjang 100 $\mathrm{mm}$, lebar $50 \mathrm{~mm}$, dan tebal 3,1 $\mathrm{mm}$. Sampel diberi lubang sedalam kurang lebih $5 \mathrm{~mm}$ dan diameter lubang kurang lebih $2 \mathrm{~mm}$ sebagai tempat untuk meletakkan kawat pengukur suhu sampel (Thermocouple) Tipe K. Kawat Thermocouple yang berfungsi sebagai alat untuk mengukur suhu sampel. Pengukuran temperatur 
menggunakan Data Acquisition System yang dilengkapi dengan Lutron Software yang terhubung dengan komputer. Rangkaian sampel dan alat pengujian seperti yang terlihat pada Gambar 1.

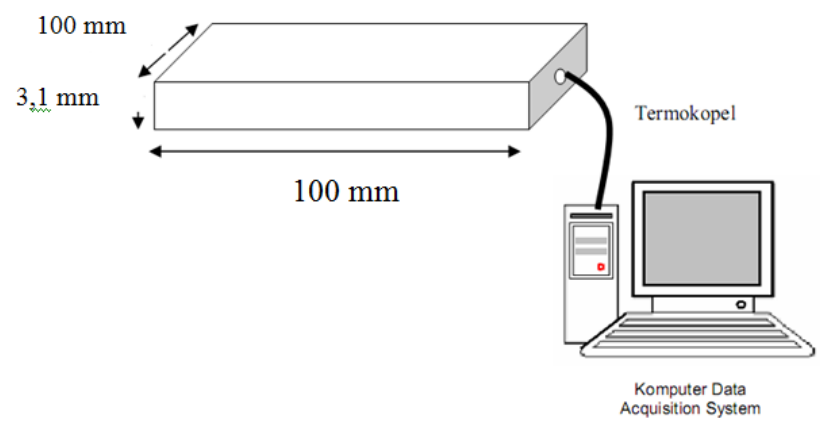

Gambar 1. Contoh rangkaian pengujian TMCP [4]

\section{Rangkaian Pengujian TMCP}

Sedangkan rangkaian pengujian TMCP secara aktual dapat dilihat pada Gambar 2.

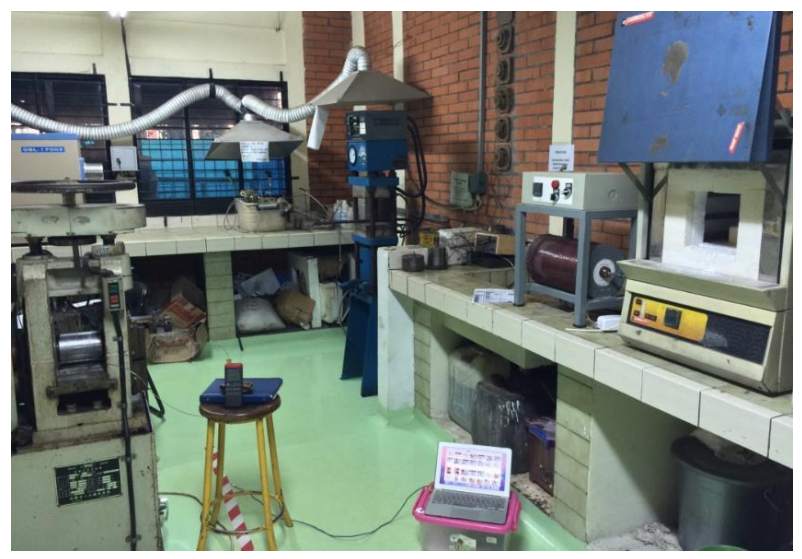

Gambar 2. Contoh rangkaian pengujian TMCP secara actual [4]

Paduan $\mathrm{Cu}-\mathrm{Zn}$ 70/30 yang digunakan ada 4 yaitu $\mathrm{A}$ adalah sampel paduan $\mathrm{Cu}-\mathrm{Zn}$ 70/30 awal yang tidak mengalami proses deformasi namun mengalami proses pemanasan awal pada suhu $700^{\circ} \mathrm{C}$ selama 90 menit lalu didinginkan dengan media dapur yang diilustrasikan dengan Gambar 3. Sedangkan B merupakan sampel paduan $\mathrm{Cu}-\mathrm{Zn}$ 70/30 yang telah dilakukan diberikan perlakuan panas berupa proses homogenisasi seperti yang telah diberikan pada sampel paduan A lalu dilanjutkan pemanasan pada suhu $300^{\circ} \mathrm{C}$ dan ditahan selama 30 menit kemudian dideformasi sebesar $30 \%$ reduksi, selanjutnya dipanaskan pada suhu $300^{\circ} \mathrm{C}$ dan ditahan selama 30 menit setelah itu dideformasi sebesar 30\% reduksi lalu didinginkan dengan media udara yang diilustrasikan dengan Gambar 4. Untuk sampel paduan $\mathrm{Cu}-\mathrm{Zn} 70 / 30 \mathrm{C}$ dipanaskan hingga suhu $700^{\circ} \mathrm{C}$ selama 90 menit lalu dilanjutkan pemanasan pada suhu $300^{\circ} \mathrm{C}$ dan ditahan selama 60 menit kemudian dideformasi sebesar $30 \%$ reduksi selanjutnya dipanaskan pada suhu $300^{\circ} \mathrm{C}$ dan ditahan selama 60 menit setelah itu dideformasi sebesar $30 \%$ reduksi lalu didinginkan dengan media udara yang diilustrasikan dengan Gambar 5. Pada sampel paduan $\mathrm{Cu}-\mathrm{Zn} 70 / 30 \mathrm{D}$ dipanaskan hingga suhu $700^{\circ} \mathrm{C}$ selama 90 menit lalu dilanjutkan pemanasan pada suhu $300^{\circ} \mathrm{C}$ dan ditahan selama 120 menit kemudian dideformasi sebesar 30\% reduksi selanjutnya dipanaskan pada suhu $300^{\circ} \mathrm{C}$ dan ditahan selama 120 menit setelah itu dideformasi sebesar $30 \%$ reduksi lalu didinginkan dengan media udara yang diilustrasikan dengan Gambar 6 . 
4 | Eka Febriyanti, dkk., Pengaruh Waktu Tahan ketika Proses Thermo Mechanical Controlled Process....

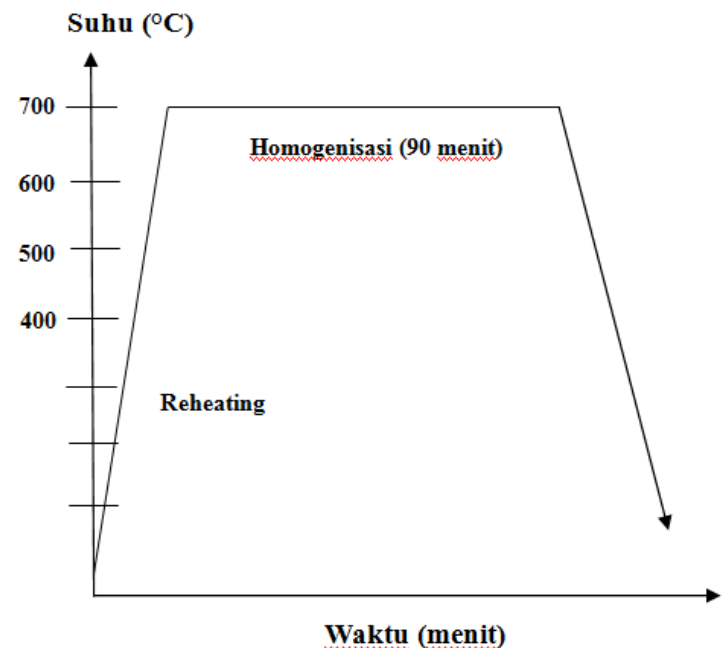

Gambar 3. Diagram tahapan homogenisasi untuk paduan $\mathrm{Cu}-\mathrm{Zn} 70 / 30$ di suhu $700^{\circ} \mathrm{C}$ selama 90 menit.

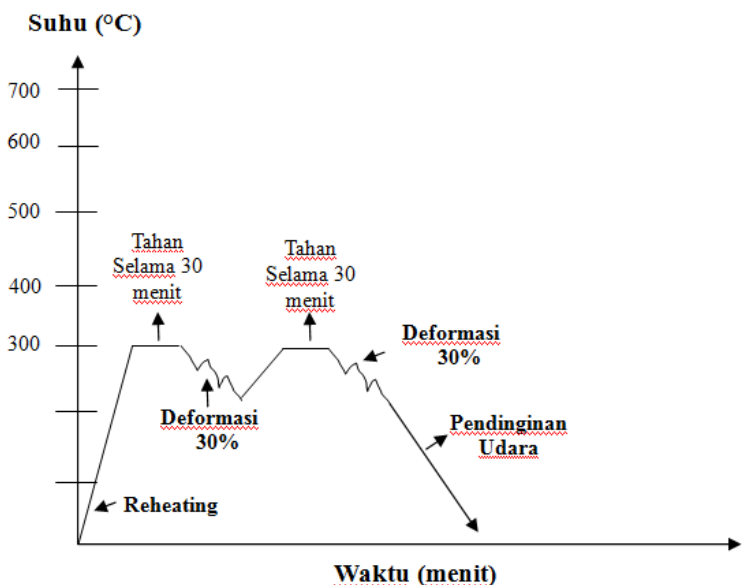

Gambar 4. Diagram tahapan TMCP pada suhu $300^{\circ} \mathrm{C}$ dengan metode double pass reversible dengan deformasi teoritis $30 \%+30 \%$ dan waktu tahan 30 menit.

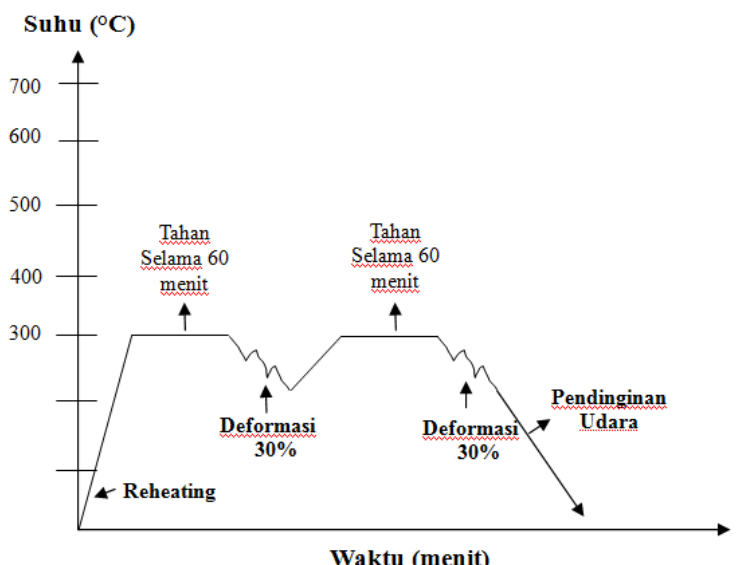

Gambar 5. Diagram tahapan percobaan TMCP pada suhu $300^{\circ} \mathrm{C}$ dengan metode double pass reversible dengan deformasi teoritis $30 \%+30 \%$ dan waktu tahan 60 menit. 


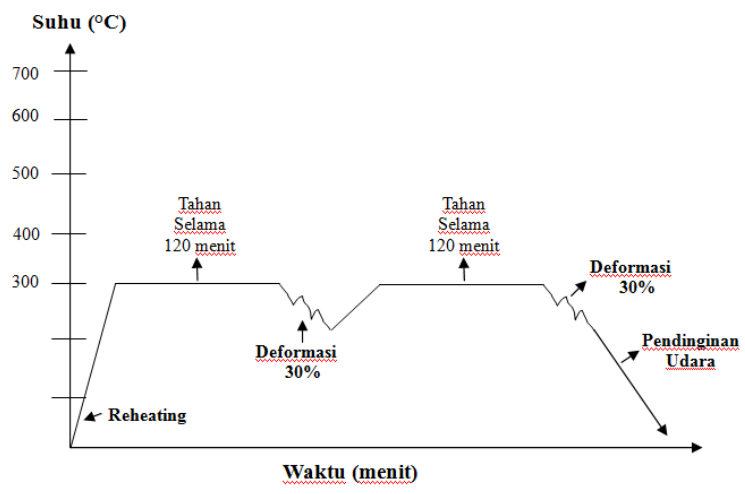

Gambar 6. Diagram tahapan percobaan TMCP pada suhu $300^{\circ} \mathrm{C}$ dengan metode double pass reversible dengan deformasi teoritis 30\%+30\% dan waktu tahan 120 menit.

Proses TMCP dilanjutkan dengan pengujian tarik. Pengujian tarik dilakukan untuk mengetahui dan menentukan respon mekanis material dari suatu konstruksi, komponen, atau rakitan fabrikasi saat dikenakan beban atau deformasi tertentu dari yang terus meningkat secara kontinyu. Pengujian dan sampel uji tarik mengacu pada standar ASTM E8 untuk mengetahui degradasi sifat mekanik material yang meliputi kekuatan, ketangguhan, dan nilai keuletan. Output data yang dihasilkan adalah berupa perubahan panjang dan perubahan beban yang selanjutnya diolah ke dalam bentuk grafik tegangan-regangan.

Benda uji tarik dibuat searah pengerolan yaitu: $0^{\circ}$ dan mengacu pada standar ASTM E8 seperti yang terlihat pada Gambar 7. Selanjutnya dilakukan pengujian tarik menggunakan mesin uji tarik Servopulser.

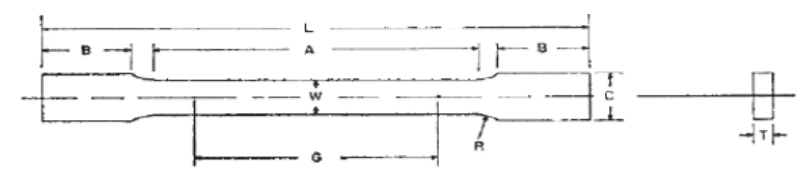

Gambar 7. Sampel uji tarik dimana $\mathrm{L}=\operatorname{minimal} 100 \mathrm{~mm}, \mathrm{G}=25 \mathrm{~mm}, \mathrm{~W}=6 \mathrm{~mm}, \mathrm{R}=6 \mathrm{~mm}, \mathrm{~A}=32 \mathrm{~mm}, \mathrm{~B}=30 \mathrm{~mm}$, dan $\mathrm{C}=10 \mathrm{~mm}$

Untuk menghitung nilai UTS (ultimate tensile strength), YS (yield strength), dan $\varepsilon$ (elongasi) dari material paduan $\mathrm{Cu}-\mathrm{Zn}$ 70/30 menggunakan persamaan sebagai berikut :

$$
\begin{aligned}
& \sigma_{\text {UTS }}=\text { Fmax } / A_{o} \\
& \varepsilon=\left(\operatorname{lmax}-1_{\circ}\right) / l o
\end{aligned}
$$

Setelah pengujian tarik dilanjutkan dengan pengamatan struktur mikro. Pengamatan struktur mikro ini bertujuan untuk melihat struktur mikro material paduan $\mathrm{Cu}-\mathrm{Zn}$ 70/30. Dalam pengamatan ini digunakan standar ASTM E3 - 01 [7] "Standard Guide for Preparation for Metallographic Specimens". Pertama-tama sampel dipotong untuk mempermudah proses pengujian metalografi. Lalu sampel dipasangkan pada blok polimer untuk memudahkan dalam proses pengamplasan dan pemolesan. Kemudian sampel diamplas dengan kertas amplas dimulai dari grit \#80, \#200, \#400, \#600, \#800, \#1000, \#1200, \#1500 (dalam mesh). Selanjutnya sampel dipoles dengan ditambahkan pasta kovac sampai mengkilap. Setelah itu sampel dietsa dengan zat etsa ferric klorida atau $\mathrm{FeCl}_{3} 10 \%$ yang terdiri atas $10 \mathrm{gr} \mathrm{FeCl} 3$ dan $100 \mathrm{ml}$ alcohol 96\%. Terakhir sampel diamati di mikroskop dengan perbesaran 100x, 200x, dan 500x menggunakan mikroskop optik.

Setelah dilakukan proses pengamatan struktur mikro lalu dilakukan pengujian kekerasan untuk membandingkan hubungan antara besar deformasi TMCP dengan tingkat keuletan material paduan $\mathrm{Cu}-\mathrm{Zn}$ 
6 | Eka Febriyanti, dkk., Pengaruh Waktu Tahan ketika Proses Thermo Mechanical Controlled Process....

70/30. Metode pengujian kekerasan yang dipakai yaitu metode kekerasan Vickers dengan menggunakan standar ASTM E 92 [8] karena ketebalan material benda uji tipis yaitu $\leq 3,1 \mathrm{~mm}$. Oleh karena itu, perlu dilakukan pengujian metode kekerasan mikro untuk mengetahui distribusi kekerasan baik di bagian tepi maupun di bagian tengah hasil warm rolling.

\section{HASIL DAN DISKUSI}

Dari hasil uji tarik diperoleh data seperti batas kekuatan tarik (UTS), perpanjangan hingga putus (\% Elongasi), dan kekuatan luluh (YS) dari paduan $\mathrm{Cu}-\mathrm{Zn}$ 70/30 yang terdapat pada Tabel 2.

Tabel 2. Data hasil uji tarik paduan $\mathrm{Cu}-\mathrm{Zn} 70 / 30$ setelah diproses TMCP.

\begin{tabular}{cccc}
\hline $\begin{array}{c}\text { Waktu } \\
\text { Tahan } \\
\text { (menit) }\end{array}$ & $\begin{array}{c}\text { UTS } \\
(\mathrm{MPa})\end{array}$ & $\begin{array}{c}\text { YS } \\
(\mathrm{MPa})\end{array}$ & $\varepsilon(\%)$ \\
\hline 0 & 314,06 & 125,41 & 53,4 \\
30 & 459,2 & 401,54 & 5,99 \\
60 & 530,36 & 462,7 & 5,54 \\
120 & 525,4 & 474,3 & 5,87 \\
\hline
\end{tabular}

Data hasil uji tarik paduan $\mathrm{Cu}-\mathrm{Zn}$ 70/30 yang telah diproses TMCP seperti yang dapat dilihat pada Gambar 8 yaitu grafik hubungan waktu tahan TMCP terhadap kekuatan tarik UTS (ultimate tensile strength), Gambar 9 yaitu grafik hubungan waktu tahan TMCP terhadap kekuatan tarik YS (yield strength), dan Gambar 10 yaitu grafik hubungan waktu tahan TMCP terhadap persentase elongasi, dimana sebelum proses TMCP (setelah proses homogenisasi pada suhu $700^{\circ} \mathrm{C}$ selama 90 menit) sampel paduan $\mathrm{Cu}-\mathrm{Zn}$ 70/30 memiliki kekuatan tarik UTS 314,06 MPa; YS 125,41 MPa; dan \% elongasi 53,4\%.

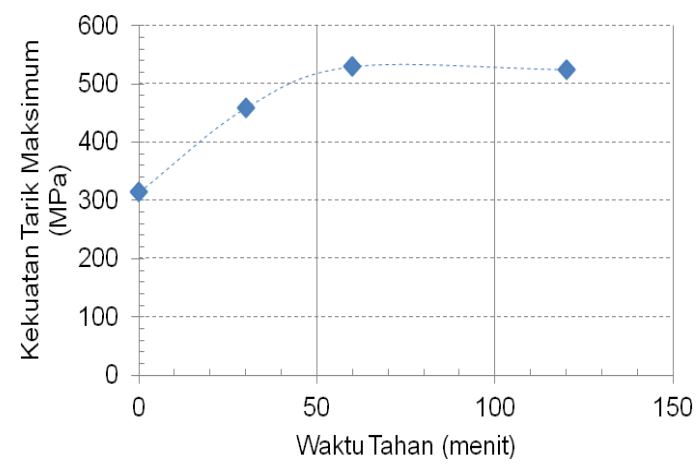

Gambar 8. Hubungan waktu tahan (menit) dengan nilai UTS (ultimate tensile strength/MPa).

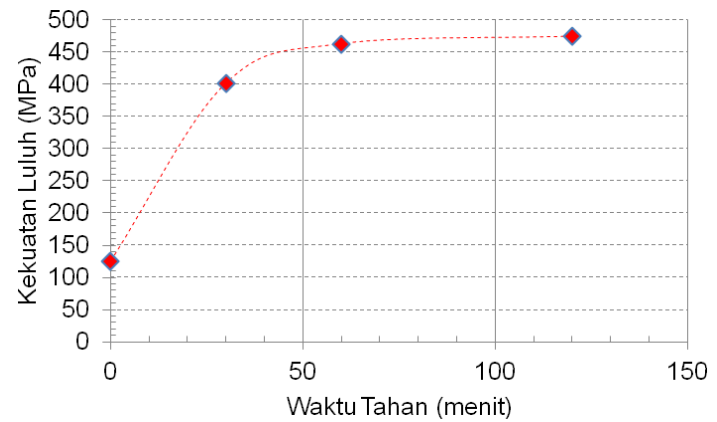

Gambar 9. Hubungan waktu tahan (menit) dengan nilai YS (yield strength/MPa). 


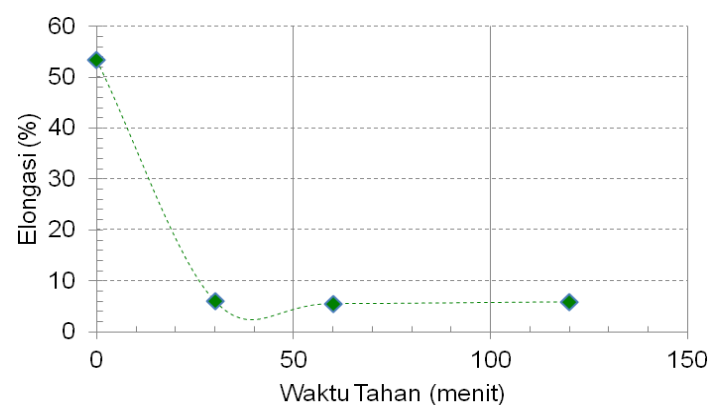

Gambar 10. Hubungan waktu tahan (menit) dengan nilai elongasi (\%).

Pada Gambar 8 menunjukkan pengaruh hubungan besar waktu pemanasan terhadap Ultimate Tensile Strength (UTS) paduan Cu-Zn 70/30. Dapat dilihat bahwa dengan lamanya waktu pemanasan yang dilanjutkan deformasi canai maka terjadi peningkatan kekuatan tarik dari 314,06 MPa hingga 525,4 MPa.

Adanya peningkatan kekuatan tarik yang dipengaruhi oleh pemanasan atau annealing dapat disebabkan oleh Anneal Hardening seperti penelitian yang dilakukan oleh Y.L. Gong dkk, dimana dilakukan cryogenic rolling pada paduan $\mathrm{Cu}-\mathrm{Al}-\mathrm{Zn}$ di suhu nitrogen cair kemudian dilakukan annealing pada suhu $150^{\circ} \mathrm{C}$ hingga $300^{\circ} \mathrm{C}$. Paduan $\mathrm{Cu}-\mathrm{Al}-\mathrm{Zn}$ dibagi menjadi 3 komposisi yang berbeda yaitu $\mathrm{Cu}-\mathrm{Al} 12,1 \%$ berat-Zn4,1\%berat, $\mathrm{Cu}-$ Al4,3\%berat-Zn22,8\%berat, dan Cu-Al2,5\%berat-Zn2,5\%berat. Pada kedua paduan dengan komposisi yang tinggi (Cu-Al12,1\% berat-Zn4,1\% berat dan $\mathrm{Cu}-\mathrm{Al} 14,3 \%$ berat-Zn22,8\% berat) menunjukkan adanya peningkatan kekuatan tarik dan pengurangan elongasi pada suhu $150^{\circ} \mathrm{C}$ hingga $200^{\circ} \mathrm{C}$ namun kemudian diatas $250^{\circ} \mathrm{C}$ sifat mekanik terjadi seperti pada annealing umumnya, namun pada paduan dengan komposisi rendah (CuAl2,5\%berat-Zn2,5\%berat) hanya terjadi perubahan sifat mekanik seperti pelunakan pada umumnya. Peningkatan sifat mekanik berupa kekuatan tarik dan pengurangan elongasi pada kedua paduan dengan komposisi yang tinggi mengindikasikan adanya fenomena Anneal Hardening yang terjadi, namun fenomena ini tidak terjadi pada paduan dengan komposisi atom terlarut yang rendah [9].

Tabel 3. Data hasil uji kekerasan paduan Cu-Zn 70/30 setelah diproses TMCP.

\begin{tabular}{ccccc}
\hline \multirow{2}{*}{$\begin{array}{c}\text { Waktu } \\
\text { Tahan } \\
\text { (menit) }\end{array}$} & $\begin{array}{c}\text { Sampin } \\
\text { g } \\
\text { Tengah }\end{array}$ & $\begin{array}{c}\text { Samping } \\
\text { Tepi }\end{array}$ & Atas & Rata-rata \\
\hline 0 & 74,91 & 77,26 & 79,36 & 77,18 \\
30 & 171,58 & 181,93 & 175,22 & 176,25 \\
60 & 171,16 & 171,94 & 168,13 & 170,41 \\
120 & 171,74 & 175,61 & 175,01 & 174,12 \\
\hline
\end{tabular}

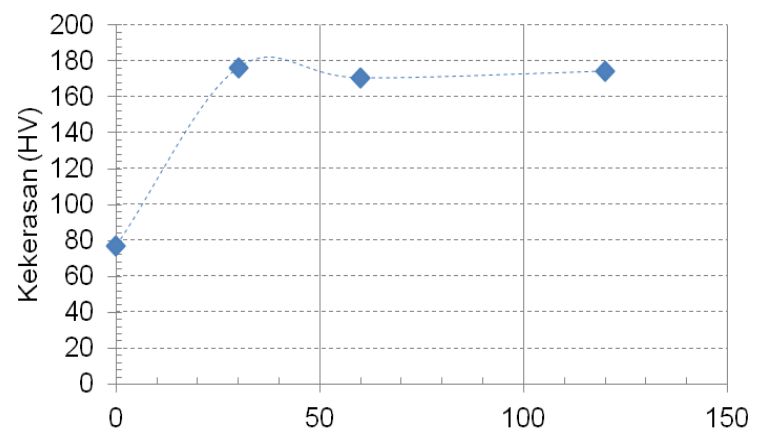

Gambar 11. Hubungan waktu tahan (menit) dengan kekerasan (HV). 
Pada Tabel 3 dan Gambar 11 menunjukkan hubungan pengaruh waktu pemanasan dengan nilai kekerasan material dan dapat dilihat bahwa nilai kekerasan memiliki kecenderungan peningkatan seiring lamanya waktu pemanasan dari 77,18 HV untuk paduan $\mathrm{Cu}-\mathrm{Zn}$ 70/30 No.1 hingga mencapai $174,14 \mathrm{HV}$ untuk paduan $\mathrm{Cu}-\mathrm{Zn}$ 70/30 No.4.

Penumpukan dislokasi pada batas butir inilah yang menghasilkan peningkatan nilai kekerasan material [1]. Seperti penelitian oleh Rini Riastuti [10], yang melakukan canai hangat terhadap baja karbon rendah berbentuk wedges pada suhu $500^{\circ} \mathrm{C}, 550^{\circ} \mathrm{C}$, dan $600^{\circ} \mathrm{C}$ dengan persentase reduksi $50 \%, 67 \%$, 75\%, dan $80 \%$. Hasilnya menunjukkan bahwa dengan peningkatan \% deformasi maka ukuran butir pun menurun sedangkan kekerasan akan meningkat. Ukuran butir halus akan meningkatkan kekerasan dikarenakan ukuran butir halus memiliki jumlah batas butir yang banyak. Batas butir merupakan tempat dimana dislokasi tertahan karena batas butir mempunyai energi tertinggi untuk memindahkan dislokasi sehingga jika jumlah batas butir meningkat, maka dislokasi akan sulit bergerak dan material akan mengalami pengerasan regang yang menghasilkan peningkatan nilai kekerasan.

Selain itu peningkatan mechanical (deformed) twin karena adanya rangkaian proses pemanasan dan deformasi seiring meningkatnya waktu pemanasan juga memiliki peran dalam meningkatkan kekerasan material dimana twin tersebut dapat berperan sebagai penghambat pergerakan dislokasi sehingga interaksi tersebut dapat meningkatkan kekuatan material. Seperti penelitian oleh Bondan T. Sofyan dan Imam Basori [11], yang melakukan canai dingin terhadap $\mathrm{Cu}-32 \% \mathrm{Zn}$ dengan persentase reduksi 20\%, 40\%, dan 70\%. Hasilnya menunjukkan bahwa dengan peningkatan \% deformasi maka twin yang terbentuk juga meningkat. Strain Hardening terjadi karena formasi dislokasi yang bergerak sepanjang bidang slip, dengan semakin meningkatnya deformasi maka twin yang terbentuk juga meningkat dan menjadi lebih dominan dari slip, mengakibatkan slip akan lebih sulit dan berdampak pada pergerakan dislokasi yang terhambat sehingga kekerasan pun meningkat.

Walaupun pada Gambar 11 menunjukkan adanya kecenderungan peningkatan kekerasan, tetapi pada waktu pemanasan 30 menit memiliki nilai kekerasan tertinggi mencapai 176,25 HV walaupun memiliki ukuran butir yang lebih besar dan kasar jika dibandingkan waktu pemanasan lainnya seperti yang terlihat pada hasil pemeriksaan mikrostruktur paduan $\mathrm{Cu}-\mathrm{Zn}$ 70/30 di Gambar 12. Kekerasan yang optimum ini dapat disebabkan oleh fenomena Anneal Hardening. Annealing merupakan salah satu perlakuan panas untuk menghilangkan tegangan sisa, melunakkan, dan meningkatkan keuletan logam. Namun untuk beberapa kasus, annealing dapat mengeraskan suatu logam dan umumnya fenomena ini ditemukan pada tembaga dan paduannya [12]. Fenomena Anneal Hardening adalah fenomena yang terjadi karena adanya mekanisme penguatan yang menghasilkan peningkatan sifat mekanik material dari hasil pemanasan pada suhu tertentu. Fenomena Anneal Hardening terjadi ketika paduan $\mathrm{Cu}-\mathrm{Zn}$ dianil pada suhu dibawah suhu rekristalisasinya berkisar antara $152-300^{\circ} \mathrm{C}$ atau lebih tergantung dari unsur paduannya. Selain itu dengan meningkatnya \% deformasi pengerjaan dingin dan waktu tahan annealing maka efek Anneal Hardening semakin meningkat. Hal ini dijelaskan oleh S. Nestorovic [5], yang meneliti perubahan kekerasan terhadap waktu tahan annealing pada suhu anil $240^{\circ} \mathrm{C}$ dimana seiring meningkatnya waktu anil maka kekerasan juga meningkat akibat dari pengaruh Anneal Hardening. Pada penelitian tersebut terjadi peningkatan kekerasan seiring meningkatnya waktu tahan annealing dimana pada waktu tertentu mencapai nilai maksimum kemudian kekerasan mengalami penurunan walaupun tidak signifikan, penurunan nilai kekerasan ini dapat disebabkan oleh material telah mengalami proses rekristalisasi walaupun belum mencapai suhu rekristalisasinya. Walaupun belum mencapai suhu rekristalisasi, material tetap dapat mengalami rekristalisasi dengan waktu pemanasan yang cukup [13].

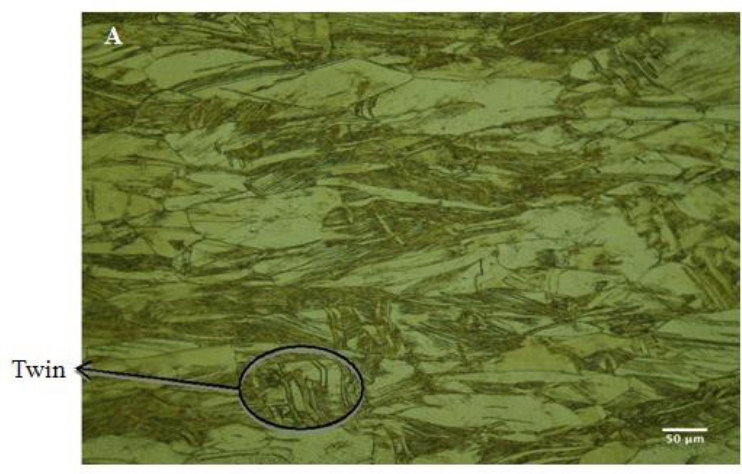



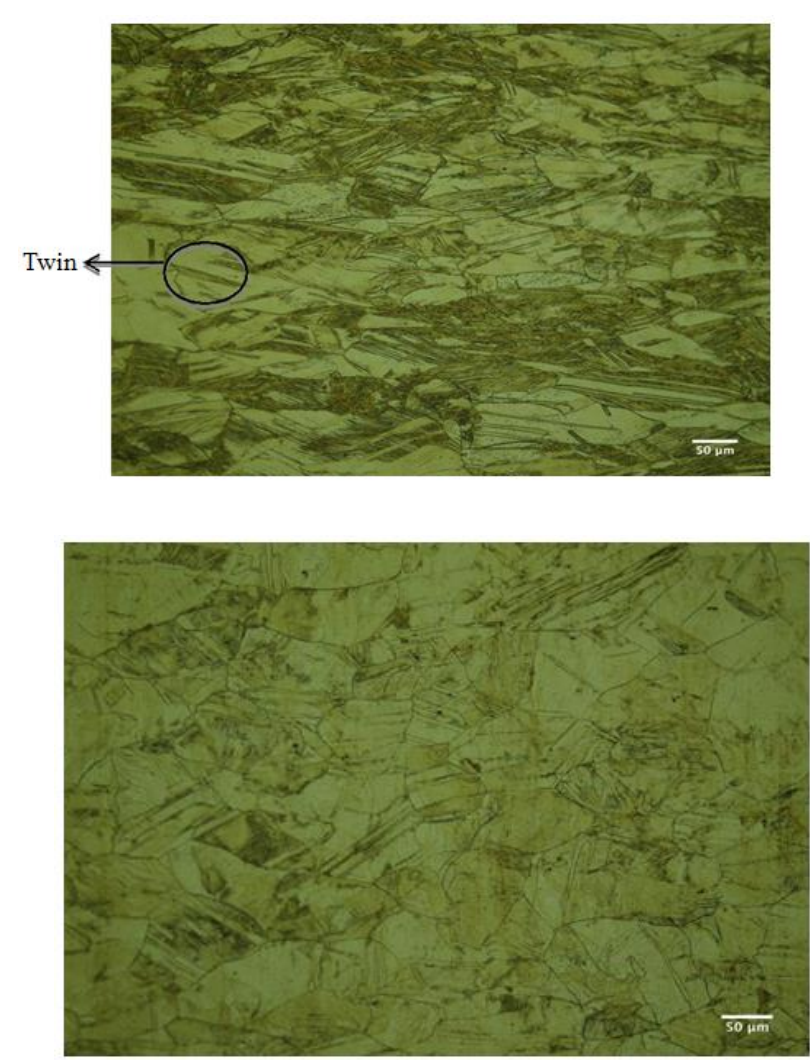

Gambar 12. Mikrostruktur paduan $\mathrm{Cu}-\mathrm{Zn} 70 / 30$ yang dilakukan TMCP di suhu $300^{\circ} \mathrm{C}$ dengan waktu tahan 30 menit (A) Posisi samping tengah, (B) Posisi samping tepi, (C) Posisi atas. Etsa : $\mathrm{FeCl}_{3} 10 \%$.

Banyak teori mekanisme yang dapat menyebabkan terjadinya Anneal Hardening karena fenomena ini memang belum banyak dikaji dan sepenuhnya dimengerti oleh para peneliti. Namun berdasarkan penelitian I. Markovic, dkk, yang melakukan pengujian pada paduan $\mathrm{Cu}-11,4 \% \mathrm{Au}$ dan paduan $\mathrm{Cu}-12,7 \% \mathrm{Au}$ yang diberi perlakuan canai dingin sebesar $60 \%$ kemudian dianil secara isokronal dari $60^{\circ} \mathrm{C}-700^{\circ} \mathrm{C}$ dan isotermal sebesar $250^{\circ} \mathrm{C}$ selama 100 jam, pada suhu $60^{\circ} \mathrm{C}-200^{\circ} \mathrm{C}$ juga menunjukkan terjadi sedikit peningkatan kekerasan sebesar $240 \mathrm{HV}$ yang dianggap sebagai pengerasan pertama kemudian dari suhu $200^{\circ} \mathrm{C}$ ke $350^{\circ} \mathrm{C}$ kembali terjadi peningkatan yang cukup jelas sebesar $310 \mathrm{HV}$ yang dianggap sebagai pengerasan kedua dan setelah $350^{\circ} \mathrm{C}$ kembali terjadi penurunan kekerasan sebagai indikasi telah terjadinya rekristalisasi. Pengerasan pertama dan kedua ini dianggap sebagai Anneal Hardening yang mekanismenya disebabkan oleh segregasi atom terlarut kepada batas butir dan cacat kisi seperti vakansi dan dislokasi. Pengujian DTA dan XRD yang dilakukan dalam penelitian tersebut juga mengindikasikan adanya pengurangan parameter kisi yang diasosiasikan dengan tersegregasinya atom terlarut dimana atom terlarut akan meninggalkan matriks tembaga sehingga terjadi perubahan parameter kisi, atom terlarut tersebut kemudian membentuk cluster yang cenderung terbentuk di daerah yang banyak vakansi seperti dislokasi atau batas butir [14].

Selain itu pada penelitian Y.L. Gong, dkk, juga membahas mekanisme yang paling umum dari Anneal Hardening yaitu segregasi atom terlarut pada dislokasi atau batas butir yang dapat menyebabkan tegangan pada kisi karena atom ini tersegregasi dalam bentuk interstisi. Tegangan yang terlokalisasi ini dapat menghambat pergerakan dislokasi serta mengurangi energi pada batas butir sehingga meningkatkan kekuatan material. Atom interstisi akan mendistorsi kisi yang menyebabkan adanya tegangan sisa yang mengelilingi interstisi. Namun, jika atom terdifusi masuk ke dalam inti dislokasi, maka atom tersebut akan menetap disana. Oleh karena itu, sekali dislokasi terjepit oleh atom interstisi maka dibutuhkan gaya tambahan untuk melepaskan dislokasi [9].

\section{KESIMPULAN}

Proses TMCP yang dilakukan pada paduan $\mathrm{Cu}-\mathrm{Zn} 70 / 30$ di suhu $300^{\circ} \mathrm{C}$ dengan waktu tahan 30 , 60, dan 120 menit menunjukkan bahwa semakin lama waktu pemanasan maka terjadi peningkatan kekerasan dari 77,18 $\mathrm{HV}$ hingga mencapai $174,14 \mathrm{HV}$ dan kekuatan tarik dari 314,06 MPa hingga 525,4 MPa dimana kekerasan paling optimum yang diperoleh adalah sebesar 176,25 HV untuk waktu pemanasan 30 menit dan kekuatan tarik optimum sebesar 530,36 MPa untuk waktu pemanasan 60 menit. 
10 | Eka Febriyanti, dkk., Pengaruh Waktu Tahan ketika Proses Thermo Mechanical Controlled Process....

Selain itu, pada penelitian ini terdapat fenomena Anneal Hardening yang disebabkan oleh tersegregasinya atom terlarut $(\mathrm{Zn})$ ke dislokasi atau batas butir yang mempengaruhi nilai kekerasan dan kekuatan tarik paduan $\mathrm{Cu}-\mathrm{Zn} 70 / 30$.

\section{UCAPAN TERIMA KASIH}

Penulis mengucapkan terima kasih kepada Kemenristekdikti selaku penyelenggara/sponsorship untuk beasiswa sehingga penulis dapat menyelesaikan penelitian ini.

\section{DAFTAR PUSTAKA}

[1] William D. Callister, Jr., "Materials Science and Engineering, An Introduction”, 6th Ed., John Wiley \& Sons, Inc., 2003.

[2] Bert Verlinden, “Thermo-Mechanical Processing of Metallic Materials", Elsevier, 2007.

[3] G. H. Akbari, C. M Sellars dan J.A Whiteman, "Microstructural Development During Warm Rolling of an IF Steel”, Acta Metallurgica, Vol. 45, No.12, hal.5047-5058, 1997

[4] Febriyanti, Eka, dkk, "Pengaruh Anneal Hardening dan \% Reduksi Warm Rolling terhadap Sifat Mekanik Paduan Cu-Zn 70/30”, Majalah Metalurgi, Vol.31, Issue 1, hal.33-42, 2016.

[5] Nestorovic, S., "Influence of Time Annealing on Anneal Hardening Effect of Cast Cu-Zn Alloy", Journal of Mining and Metallurgy, Vol.39, Issue (3-4)B, hal.489-497, 2003.

[6] ASTM B36M-13, "Standard Specification for Brass Plate, Sheet, Strip, and Rolled Bar", ASTM, 2003

[7] ASTM E3-01, "Standard Guide for Preparation for Metallographic Specimens", ASTM, 2003

[8] ASTM E92, "Standard Test Methods for Vickers Hardness of Metallic Materials", ASTM, 2003

[9] Y.L. Gong, dkk, "Unusual Hardening Behaviour in Heavily Cryo-rolled Cu-Al-Zn Alloys during Annealing Treatment", Elsevier, 2016.

[10] Rini Riastuti, R.Bastian M., Dedi Priadi, and E.S.Siradjh, "Grain Refinement through Warm Rolling of Wedge-shaped Low Carbon Steel”, Advanced Material Research, Vol.383, Issue 390, hal.5869-5873, 2012.

[11] Bondan T. Sofyan dan Imam Basori, "Effects of Deformation and Annealing Temperature on the Microstructure and Mechanical Properties of $\mathrm{Cu}-32 \% \mathrm{Zn}$ Brass", ARPN Journal of Engineering and Applied Sciences, Vol. 11, No. 4, 2016.

[12] P.Zhang, X.H. An, Z.J Zhang, T.G.Langdon, dkk, "Optimizing Strength and Ductility of Cu-Zn Alloys through Severe Plastic Deformation”, Scripta Materialia, Vol. 67, hal.871-874 2012.

[13] H. L. Walker. "Grain Sizes Produced by Recrystallization and Coalesence in Cold-Rolled Cartridge Brass", Bulletin University of Illinois, 1945.

[14] I. Markovic, dkk, "Study of Anneal Hardening in Cold Worked Cu-Au Alloy", Elsevier, 2016. 